\title{
CHALUENGES TO COMPLIANCE WITH CORPORATE GOVERNANCE MECHANISMS AND ACCOUNTABILITY IN EMERGING MARKETS: EVIDENCE FROM LIBYAN LISTED COMPANIES
}

\author{
Ismail Elshahoubi ${ }^{*}$, Fathi Eltraiki ${ }^{* *}$ **** Jamal Jaballa ${ }^{* * *}$, \\ Emhemed Bazina \\ * Corresponding author, Misurata University, Misurata, Libya \\ Contact details: Misurata University, 00218.512627350, Misurata, Libya \\ ** Jinan University, Tripoli, Lebanon \\ *** Megatrend University, New Belgrade, Serbia
}

\section{OPEN ACCESS}

How to cite this paper: Elshahoubi, I., Eltraiki, F., Jaballa, J., \& Bazina, E. (2019). Challenges to compliance with corporate governance mechanisms and accountability in emerging markets: Evidence from Libyan listed companies. Journal of Governance \& Regulation, 8(3), 24-41. http://doi.org/10.22495/jgr_v8_i3_p2

Copyright $@ 2019$ The Authors

This work is licensed under a Creative Commons Attribution 4.0 International License (CC BY 4.0).

https://creativecommons.org/licenses/by/ 4.0/

ISSN Print: 2220-9352 ISSN Online: 2306-6784

Received: 23.05.2019 Accepted: 17.07.2019

JEL Classification: G3, G30, G34, G38 DOI: $10.22495 /$ jgr_v8_i3 p2
This study aims to investigate the level of compliance with CG mechanisms and accountability in Libyan listed companies. It adopts a qualitative approach, using semi-structured interviews to collect the required data from two broad stakeholder groups: internal stakeholders (ISG) and external stakeholders (ESG). The findings of this study provide evidence that Libyan listed companies are to some extent committed to implementing CG mechanisms, but that CG and accountability practices are still at an early stage of development in the country and there are significant weaknesses in terms of practice. Listed companies' commitment is most evident in their adherence to the BoD mechanism, but levels of disclosure and transparency are barely satisfactory; interviewees argued that at present, disclosure and transparency practices in Libya are designed only to meet local, not international, requirements. Listed companies have also taken practical steps towards meeting the LCGC's requirements regarding the internal and external audit mechanisms, but the general view among ISG and ESG interviewees was that these mechanisms are currently not robust enough to ensure strong internal control systems. Finally, in terms of the shareholders' rights mechanism, majority shareholders are seen to enjoy much greater protection, both legally and in practice, than minority shareholders. The results of the study reveal that the lack of knowledge and awareness about the concept of CG, the weakness of the Libyan legislative environment and the lack of accountability mechanisms are the most significant factors inhibiting the advance of CG in the Libyan environment. This study helps to enrich our understanding and knowledge of current CG and accountability practices by being the first to investigate CG mechanisms and accountability in Libyan listed companies.

Keywords: Corporate Governance Mechanisms, Accountability, Libyan Listed Companies

Authors' individual contribution: Conceptualization - I.E., F.E., J.J., and E.B.; Methodology - I.E. and F.E.; Formal Analysis - I.E., F.E., J.J., and E.B.; Writing - Original Draft - I.E., F.T., J.J., and E.B.; Writing - Review \& Editing - I.E.; Supervision - I.E. and F.E. 


\section{INTRODUCTION}

Over the last two decades, the debate about CG has intensified, driven by a string of major corporate collapses in the US and elsewhere e.g. WorldCom, Enron, Parmalat, Arthur Anderson, and Tyco (Steger, 2014; Hamidi \& Gabrielsson, 2014; Briano-Turrent \& Rodríguez-Ariza, 2016). Subsequent investigations have revealed the role played by weak or nonexistent governance structures (Ghafran \& O'Sullivan, 2017) in these corporate failures, which have had long-term economic consequences at both national and global levels (Monks \& Minow, 2004; Al-Baidhani, 2015). As a result, interest in CG has grown exponentially, with researchers, theorists and regulators around the world calling for renewed attention to be paid to the improvement of CG and accountability, and international initiatives being launched to improve CG practice (Al-Matari et al. 2012) and develop systems that protect the rights and interests of all stakeholders. The most significant of these initiatives is the OECD's creation of a set of internationally accepted principles of CG, the purpose of which is to protect companies from crises by ensuring they follow best practice (OECD, 2004).

However, despite the fact that CG has become a matter of global concern, most of the research that has been produced over the last twenty years has focused primarily on developed countries. Much less attention has been paid to CG in developing countries such as those in the MENA region (Larbsh, 2010; Iswaissi \& Falahati, 2017; Msli, 2018). It is only in recent years that research interest has begun to grow in the extent to which developing countries are implementing CG codes at firm level, the factors facilitating and impeding their implementation, and the consequences of implementation at national level (Andreasson, 2011; Salterio et al., 2013; Mahadeo \& Soobaroyen, 2016; Ntim et al., 2017). Claessens and Yurtoglu (2012) highlight the particular importance of understanding how CG practices in developing countries compared with best practices, arguing that such an understanding is central to improving CG mechanisms in these countries and, in turn, increasing listed companies access to finance, raising performance and ensuring fair treatment for all relevant stakeholders. There are significant differences between developed countries and Libya in terms of attitudes towards CG and accountability. Leuz et al., (2003) concluded that in developing countries with weak economies, investors have few rights, regulation is not enforced and the earnings of higher level management are opaque. Elshahoubi (2019) observes that the concept of CG was not introduced to Libya until 2005, the Libyan laws do not currently have a legal/regulatory framework that supports CG and accountability practices. In addition, the level of disclosure and transparency in these companies is barely satisfactory, since, at present, disclosure and transparency practices in Libya are designed only to meet local requirements.

The study aims to respond to the dearth of practical evidence on CG mechanisms and accountability in Arab and developing countries by providing insights from both internal and external stakeholders in the Libyan environment to investigate the extent to which CG mechanisms and accountability are being implemented in Libyan listed companies. The research also offers an initial picture of those factors that have the most significant inhibiting effects on CG and accountability practices within these listed companies. In particular, it focuses on answering the following questions:

- To what extent are Libyan listed companies committed to implementing $C G$ mechanisms and accountability?

- What factors inhibit CG and accountability practices in Libyan listed companies?

One of the most significant contributions of the study is that it addresses a gap in the accounting literature by exploring a context that is still poorly understood. By offering new, primary evidence from a context that is legally, culturally, politically and socially distinct from those examined in most previous studies, and by representing a range of stakeholder perspectives, the research may help deepen our understanding of the concepts of CG and accountability. Consideration of the Libyan context is especially important as CG practice in the country is still in the early stages of development, and little is known about how CG and accountability are understood and enacted by its listed companies. The study also contributes to the literature with its discussion of the factors that are inhibiting the development of CG and accountability practices in these companies. These findings also provide empirical evidence upon which policymakers and practitioners can draw to improve CG and accountability practices in the Libyan environment.

\section{LITERATURE REVIEW}

\subsection{Concept of corporate governance (CG)}

Although a subject of growing importance to researchers, academics, regulators, professional bodies and policymakers around the world (Sternberg, 2004), there is still no genuine consensus on how the concept of CG should be defined (Solomon, 2013). Solomon (2010) argues that definitions differ depending on the country, on whether the person concerned is a policymaker or theorist and, if the latter, which perspective they favour.

Corporate literature offers numerous definitions of CG, reflecting a range of perceptions and points of view. These definitions may be divided into two groups: narrow and broad definitions. Narrow definitions focus on the relationship between the company and its shareholders; thus, Keasey et al. (1997) state that: "In the narrowest sense, companies may be described as a formal system of accountability of senior management to shareholders" (p. 2). MacAvoy and Millstein (2003) call CG "a set of structured relationships that determine authority and responsibility for the conduct of an organization and its management" (p. 47). These definitions see CG as essentially a mechanism for managing the company in order to maximize shareholders' wealth (Allen, 2005).

Broader definitions take a more comprehensive view, going beyond shareholders to encompass the interactions between the full range of stakeholders, including customers, employees, creditors, suppliers, and society as a whole (Baker \& Owsen, 2002). CG means company management that explains the relationship between a number of parties within the company that determine the 
vision and performance of the company (Tulung \& Ramdani, 2018). The appropriate practice of CG or known as good CG can help the shareholders to know the condition of the company through the disclosure of accurate, timely, and transparent financial performance. Thus, Prowse (1998) defines CG as "rules, standards, and organizations in an economy that govern the behaviour of corporate owners, directors, and managers and define their duties and accountability to outside investors, i.e., shareholders and lenders" (p. 2). Most countries favour broader definitions, even though they may disagree on how best to implement CG in practice (Braendle et al., 2013). These definitions make it clear that accountability and corporate responsibility do not stop with shareholders but extend to all relevant stakeholders and even society as a whole, and that the company should seek to resolve any conflicts of interest between different stakeholder groups. Essentially, the broad definitions reflect the idea that corporations should behave in a socially responsible way.

In both groups of definitions, CG is highly concerned with accountability, whether this is to a narrow or broad group of interests. This is supported by Solomon (2013), who argues that similarities exist in the various definitions of CG, the most important being the notion of accountability. While narrow definitions see this accountability as owed only to shareholders, broader definitions see shareholders as just one of several stakeholder groups (others include lenders, employees, investors, customers, suppliers, and government auditors) to whom the company is accountable.

\subsection{Definition of accountability}

The concept of accountability has existed since ancient times (Gray \& Jenkins, 1993). It is the subject of sometimes contentious debate in all corners of the world where people enter into business and social relationships (Gray et al., 2014). In the business world, these relationships, and the issue of accountability have been complicated by the separation of ownership and management. Some researchers into accountability have responded by adopting agency theory to clarify the relationship between owner and manager and to resolve the resulting conflicts of interest (Brennan \& Solomon, 2008; Gray \& Jenkins, 1993). Others, however, have employed alternative theoretical frameworks to extend the scope of corporate accountability to encompass a broader range of stakeholder groups (Parker, 2007).

Sinclair (1995) asserts that: "Nobody argues with the need for accountability" (p. 219), and numerous theories have highlighted its importance indeed, the growing emphasis being placed on CG has been largely driven by widespread concerns about the accountability of agents towards owners and other stakeholders. Despite this, however, there is no real consensus on how the concept should be practiced or even defined. Accountability practices may be influenced by the surrounding environment (Alshehri, 2012), but despite being the focus of a wide range of studies, there has been relatively little research on how the concept of accountability is understood and practiced from different perspectives (Brennan \& Solomon, 2008).

\subsection{Mechanisms of CG}

Supporters of agency theory emphasize that effective CG mechanisms are important to protect shareholders' rights and interests (Fama \& Jensen, 1983). Dalwai et al. (2015) argue that it is necessary to recognize what impact these mechanisms are having, and to monitor them constantly to ensure that the interests of agents do not conflict with those of other stakeholders. Wahba (2015) also argues that CG mechanisms should be regularly evaluated. There is a broad consensus among researchers that CG mechanisms can be divided into two groups: internal mechanisms (established by the company) and external mechanisms (established by the market) (Al-Baidhani, 2015). However, they disagree about which mechanisms belong in each group and how these mechanisms affect the overall CG system (Jensen, 1993). It is perhaps not surprising then that they have not yet found a way of classifying CG mechanisms that suits all countries (Weir et al., 2002).

Brennan and Solomon (2008) found that both accounting and finance researchers tend to concentrate on internal mechanisms, but while the former generally focus on disclosure, transparency and audit committees, the latter tend to concentrate on mechanisms related to the $\mathrm{BoD}$ and its performance. In the following explanation of the CG framework applied in this study, sub-sections discuss both internal CG mechanisms (the BoD, internal auditing, disclosure, and transparency) and external mechanisms (shareholders' rights and external auditing).

\subsection{The board of directors (BoD)}

As the key link between management and shareholders (Al-Daoud et al., 2015; Yoo \& Reed, 2015) and the senior internal governance mechanism (Abdullah, 2016), the BoD plays a crucial role in CG practice (Atkins et al., 2018). Cadbury (2002) attributes central importance to the board, defining it as "the bridge between those to whom the board is accountable and those who are accountable to the board" (p. 31). It is the main internal governance mechanism in charge of supervising and controlling executive directors' decisions (Al-Manaseer et al., 2012) and resolving any conflicts of interest between managers and other stakeholders (Halal et al., 2014). Its responsibilities may include developing a longterm strategy, determining the compensation of corporate executives, evaluating the performance of managers and improving internal control systems (Cimerovaa et al., 2015; Brooks, 2016). Such is the importance of the BoD that its responsibilities and expectations concerning its performance are often set out in law (Volonté, 2015). This legislation usually demands that the BoD protects shareholders' rights and interests by monitoring the performance of and offering advice to senior management (Keay \& Loughrey, 2015; Bankewitz, 2016). Moreover, firms' financial performance is highly affected by how the board of directors' mechanism is implemented. For instance, board composition may play a pivotal role in enhancing the monitoring of managers' decisions and choices (Alqudah \& Azzam, 2019). The Cadbury Report (1992) pays particular attention to the BoD as 
it considers this one of the most important mechanisms for achieving CG best practice.

Under Libyan law, the board is responsible for governing and directing the firm, which it does by formulating organizational plans, policies, and objectives; overseeing the company's internal managerial and financial systems; determining the responsibilities of the management and their compensation; organizing shareholder meetings; and presenting the annual report detailing the company's activities (LCGC, 2007; 2010). In practice, however, there is no conclusive empirical evidence that boards in Libyan listed companies perform their roles and responsibilities in accordance with the requirements of the LCGC. This was, therefore, an area of investigation in this study.

\subsection{Disclosure and transparency}

Disclosure and transparency are the twin pillars of CG (Doski, 2015). As there is widespread support for the view that effective measures for ensuring disclosure and transparency are central to achieving control of the company's activities (Solomon, 2013), their importance is stressed in numerous CG codes and reports (Al-Sawalqa, 2014).

The issue of disclosure has received an increasing amount of interest from researchers, some of whom have provided their own definitions. Oliver (2004), for instance, defines disclosure as offering information in advance (as opposed to permitting users to obtain information after the fact, which is how he defines transparency). Bushman et al., (2004), meanwhile, define disclosure as "firms making available specific information to people outside publicly-traded firms" (p. 207). The OECD Principles (2004) call for the full and timely disclosure of all relevant information to shareholders, including information relating to the company's financial position, performance and supervision arrangements. Nam and Nam (2004) highlight two key reasons why this is critical: shareholders need access to this information to protect their own interests and right, and it is central to preventing managers from making suboptimal decisions and majority shareholders from engaging in activities that adversely affect minority shareholders. Focusing particularly on the disclosure of financial information, Archambault and Archambault (2003) describe this as a complex process influenced by a range of financial, economic, cultural and political factors. In the case of Libya, for example, the failure of commercial banks to comply with even compulsory disclosure requirements between 2000 and 2006 (Kribat et al., 2013) was largely due to the absence of accounting standards, which permitted organisations even in the same sector to implement accounting principles, methods, rules and measures in different ways (Ahmad \& Gao, 2004).

Enhanced disclosure leads to enhanced transparency - one of the most important goals of CG reform all over the world (Solomon, 2013). In other words, disclosure and transparency are interrelated, and both are crucial to achieving effective CG (Jhunjhunwala \& Sharvani, 2011). Improving the levels of disclosure and transparency is also likely to help reduce agency costs as the company allows information about its activities and financial position to flow to shareholders, reducing the level of information asymmetry between investors (both existing and potential) and directors (Mugaloglu \& Erdag, 2013).

The desire to increase the level of corporate transparency has been a major driver of initiatives to reform CG practice (Shiri et al., 2016). The UK Combined Code (2003), for example, recommends that transparency be enhanced by making the chairmen of the BoD, audit, remuneration and nomination committees available to answer questions at the general assembly meeting. The link between transparency and CG is also a recurring theme among researchers. Summers and Nowicki (2006) define transparency as a set of actions that together establish reliable CG, while Khiari and Karaa (2013) describe it as one of the best proofs of good CG because it guarantees the disclosure of both financial and non-financial information. Discussion of transparency generally tends to concentrate on the extent to which the offered disclosure is in line with users' requirements and whether it is compulsory or voluntary (Ho et al., 2012).

Libya's corporate legislation addresses the requirement for accounting disclosure in Article No. 572 of the Libyan Commercial Law (LCL, 1972), which states that the managers of joint-stock companies must prepare lists of income, a balance sheet and a report on the company's activities each financial year. Disclosure and transparency are also at the heart of Act No. 11 (2010), which covers the duties and jurisdiction of the General Board of the LSM. Finally, the LCGC (2007) stipulates that Libyan listed companies must disclose what has and what has not been applied in respect of the CG rules. The provision, therefore, exists within the law, but there is no definitive evidence regarding the level of disclosure and transparency prevailing within Libyan listed companies in practice. Accordingly, this issue was investigated in this study.

\subsection{Internal and external auditing}

Both the internal and external audit mechanisms play an important role in enhancing the quality of CG systems (Abdulsaleh, 2014). They are both fundamental to the formation of an effective CG structure, as is the interaction between the two (Alzebana \& Sawan, 2015). Gil et al. (2012) conclude that in banks with good CG, there is strong cooperation between the two functions.

Corporate scandals over the last decade have underlined the importance of the internal audit function (Eulerich et al., 2017). Al-Matari et al. (2014) see the internal audit mechanism as contributing significantly to the company's ability to achieve its objectives, while Hutchinson and Zain (2009) argue that it is the main mechanism strengthening the company's management and supporting the audit committee. The internal audit function is in turn supported by this committee (Ahmad et al., 2009), part of whose job is to test the design and implementation of the company's internal control system and the credibility and fairness of its financial reports. The relationship between the internal audit function and the audit committee is important to both sides; one of the key responsibilities of the audit committee is to support 
the independence of the internal auditors so that they can carry out their duties properly, while the committee relies on the information provided to it by internal auditors to perform its oversight role (Al-Baidhani, 2015).

Empirical studies of the internal audit function in MENA countries include those by Oussii and Takatak (2015), who reveal that in Tunisian listed companies, internal auditors focus only on financial auditing and internal control systems and are subject to restrictions that weaken their independence and limit the scope of their intervention, and Ebaid (2011), who shows that while most Egyptian listed companies have an internal audit department, they tend to lack independence, qualified staff, and management support. Like Oussii and Takatak, Ebaid notes that the role of the internal audit is generally limited to the financial audit, even though its formal duties theoretically extend to cover administrative and technical auditing. Finally, he concludes that the interaction between internal and external auditors remains weak. These findings suggest that the internal audit function within Egyptian listed companies still faces several challenges that impact negatively on its effectiveness in terms of CG.

The external audit function is designed to strengthen investor confidence by making the company's financial disclosure more reliable and increasing transparency (Suwaidan \& Qasim, 2010; Khalid et al., 2016). Hired by shareholders on a yearly basis, external auditors are responsible for producing an independent and impartial evaluation of the firm's processes and systems, including the annual financial statement detailing operational outcomes and its financial position (Alabede, 2012). This assessment is then submitted to the shareholders (Al-Thuneibal et al., 2011). The external auditor's role in maintaining good CG is broadly acknowledged (Alabede, 2012); most CG codes stipulate that one or more external auditors should be chosen to monitor the company's processes and whether or not they are in compliance with international accounting standards (Abdulsamad et al., 2018). As a consequence, external auditors are more highly regarded in the framework of CG than internal auditors.

The LCGC (2007) stipulates that: 1) Libyan listed companies must have an effective internal control system; 2) internal auditors should provide a quarterly report to the BoD and the audit committee describing the extent of the company's compliance with the laws and rules that regulate its activities; 3) the BoD should determine the objectives, functions and terms of reference of the internal audit in Libyan listed companies. With regard to the external audit, the LCGC (2007) states that Libyan listed companies should choose an external auditor registered in the LSM to review their financial statements. It stipulates that the external auditor's main duty should be to express an impartial opinion on the accuracy of the financial statement as a reflection of the company's financial position and results. However, there is no definitive evidence that Libyan listed companies are practically committed to these requirements. Accordingly, this was investigated in this study.

\subsection{Shareholders' rights}

The rights of shareholders are usually stipulated in company laws and regulations, and protecting these rights is considered the essence of good CG practice. The importance of protecting shareholders' rights is highlighted in many CG codes and principles, including those issued by the OECD in 2004 (Shanikat \& Abbadi, 2011). Implementing procedures to protect the rights of shareholders directly increases confidence in the company (Klapper \& Love, 2004). These procedures include maintaining clear records of ownership and share trading, giving shareholders regular and timely information about the company's activities, and allowing them to participate in general assembly meetings and to elect and remove from office members of the BoD. Finally, they should be given warranties of dividend distribution (Zattoni \& Judge, 2012)

The OECD's second principle (2004) states that CG should guarantee equal treatment for all shareholders, including minority shareholders and foreign subscribers, and that companies should set in place a system and procedures to ensure that shareholders have the same voting rights whether they are inside or outside the country where the company is located. Murphy and Topyan (2005) point to the particular importance of protecting the rights of minority shareholders, who may be less active within the company than majority shareholders. Chhaochharia and Laeven (2009) argue that a company's ability to offer this protection is enhanced by adopting good CG, while La Porta et al. (1999) look at this relationship from the opposite direction, suggesting that the protection of minority shareholders' rights is a prerequisite to achieving good CG, given that "corporate governance is, to a large extent, a set of mechanisms through which outside investors protect themselves against expropriation by insiders" (p. 4).

A number of researchers have highlighted the issues associated with protecting shareholder rights in developing countries in particular. Al-Haddad et al., (2011) describe this as the key problem facing corporations in these countries, while Ahunwan (2002) and Al-Gharaibeh et al. (2013) observe that conflicts between managers and shareholders are common, often exacerbated by poorly-functioning capital markets, information asymmetry and a lack of infrastructure. Additional problems arise because majority shareholders often seek to take control; as La Porta et al., (1999) point out, this creates agency problems not only between corporate managers and their shareholders but also between majority and minority shareholders.

In Libya, shareholders' rights in joint-stock companies listed in the LSM are protected by legislation such as the LCGC (2007) and Act No. 23 (2010), which contains a range of articles addressing the same concerns as addressed in the OECD Principles. Article No. 155, for example, refers to shareholders' rights to attend general assembly meetings, vote and access information about the company's activities. Article No. 235 refers to the distribution of dividends to shareholders and share disposal rights. Again, however, there is no definitive evidence regarding whether these rights are protected in practice within Libyan listed companies. Accordingly, this issue was investigated in this study. 


\section{ENVIRONMENT OF CG IN LIBYA}

In 2005, the Central Bank of Libya (CBL) issued the first Libyan Corporate Governance Code (LCGC). This set out basic guidelines regarding CG practice for commercial banks in Libya, though these were advisory rather than mandatory. The code was divided into five main sections (CBL, 2005). The first discussed the underlying principles of CG and its importance in ensuring the credibility of banking transactions and highlighted examples of international best practice. The second section set out the standards for appointing board members and senior management and explained what both groups should do in order to perform their duties effectively and efficiently. The third section concentrated on the BoD's role in selecting and supervising executive management, its most important tasks, and how it should interact with the executive management. The fourth section highlighted the duties and responsibilities of the BoD in terms of its formulation and monitoring of targeted plans and policies, while the fifth section focused on its role in auditing and internal control. This section also addressed the main role played by internal auditing, internal control systems and the audit committee (Zakari \& Elshahoubi, 2018).

In 2007, the Libyan Stock Market (LSM) issued a second LCGC geared towards protecting the rights of shareholders and other stakeholders. Aimed specifically at listed companies, it includes a number of articles relating to the duties and responsibilities of the BoD, the formation of sub-committees such as the audit, nomination and remuneration committees disclosure and transparency, the internal and external audit functions and the rights of shareholders and stakeholders. Once again, however, the code was/is advisory (it remains in force), with the only mandatory article being the requirement that companies must disclose which articles they have not complied with and why (Masoud, 2013; Zakari, 2014).

In 2010, the CBL, seeking to raise the level of performance of commercial banks, replaced the 2005 LCGC with a new, compulsory code. In the same year, the government enacted Law No. 11, which provided for the creation of the Libyan Stock Market Authority (LSMA), an independent body (though working under the supervision and control of the Ministry of Economic Affairs) tasked with regulating and monitoring the LSM. Law No. 11 (2010) sets out a series of measures designed to enhance the operation of the LSM and to increase the level of transparency therein so that more domestic and foreign investment might be attracted into the Libyan environment. One of these measures is the requirement that all necessary information be properly disclosed to investors, including all relevant statistics, biographical and financial details about board members, externally certified financial statements, an annual list of shareholders and any information that could affect the share price in the market (Zakari \& Elshahoubi, 2018).

In conclusion, since 2005, the Libyan government and the CBL have launched a series of legal and regulatory initiatives designed to foster more effective CG. Despite this, however, CG practice in the Libyan environment is still in its early stages and, as numerous researchers have observed
(Pratten \& Mashat, 2009; Hamuda \& Sawan, 2014; Faraj \& El-Firjani, 2014; Zagoub, 2016; Iswaissi \& Falahati, 2017), there are still significant obstacles to be overcome.

\section{THEORETICAL FRAMEWORK}

A number of different theoretical frameworks have been developed to explain the impact of CG (Solomon, 2013). Some of these frameworks are better suited to some environments than others, and they vary from one country to another (Mallin, 2013), but while they represent a range of perspectives, they share a number of common denominators. Agency theory is the dominant theory in this field both in terms of its popularity with researchers and its influence on the development of CG practice (Patrick et al., 2015), but a number of researchers have argued that the complex nature of the phenomenon requires a multi-theoretical approach (Sharma, 2013). Accordingly, researchers have employed a range of theoretical perspectives to analyze and interpret CG practice, including legitimacy theory. The assumptions and limitations of this theory are discussed in the following subsection.

\section{Legitimacy Theory Perspective}

Accounting researchers have paid increasing attention to legitimacy theory over the last decade (Hoque, 2006). Suchman (1995) defines legitimacy as "a generalized perception or assumption that the actions of an entity are desirable, proper, or appropriate with some socially constructed systems of norms, values, beliefs, and definitions" (p. 574). Legitimacy theory supposes that companies will obtain the support of main stakeholders so long as their activities are regarded as useful or acceptable to society. It assumes a close social relationship between the company and the society that surrounds it; both operate according to a social contract, under which the company enjoys the protection of the government's laws and regulations and is in turn expected to manage its operations in an ethical manner (Patrick, Paulinus, \& Nympha, 2015). The theory regards the needs of organizations, managers, and stakeholders as components within a cultural and institutional framework (Suchman, 1995); the activities of the company must have a social value consistent with the values of the society in general, or the company's legitimacy will be undermined.

In this perspective, CG systems are seen as a tool to ensure that companies operate for the good of stakeholders (Judge et al., 2008). The primary way companies legitimize their activities is by enhancing disclosure and transparency, including their disclosure of their CG practices (Ntim \& Soobaroyen, 2013). According to Deegan et al. (2000), "organizations utilize their annual report as a means of influencing society's perception of their operations, and as a means of legitimizing their ongoing existence" (p. 101). They may also seek to demonstrate the social value of their activities, and forestall any criticism (Jouha, 2015), by setting out for the public their social and environmental impacts (both positive and negative) in disclosure reports. A number of researchers have examined these social and environmental reports and 
identified a relationship between company disclosure and community expectations (Deegan, 2004). They explain this relationship in terms of legitimacy theory, arguing that organizations use strategies such as disclosure to prove to the surrounding community that they are attempting to comply with their expectations (Hoque, 2006). Corporate operations are constantly changing in response to these community expectations because, as Meyer and Rowan (1977) point out, organizations can only achieve legitimacy by ensuring that their organizational structures and practices are consistent with current social principles, behaviours, and values. Companies who see their legitimacy as under threat are likely to take a range of actions, including raising the level of disclosure about CG practices, to change stakeholders' perceptions and reassure them that their activities are socially desirable (Reverte, 2009).

Legitimacy theory sees CG-related disclosure as central to maintaining legitimacy because of its importance in polishing corporate reputations and addressing public concerns (Filatotchev \& Nakajima, 2014). However, it can also add corporate value; demonstrating conformance to social standards and expectations reassures markets and investors, who see it as an indicator of accountability (Certo et al., 2001), and makes it easier for companies to enlist the support of powerful stakeholders and access the resources they need (Branco \& Rodrigues, 2008; Liao et al., 2015; Low et al., 2015).

Legitimacy theory appears to be a useful lens for interpreting the antecedents of CG disclosure and the influence of good CG on company performance. It has been employed in numerous studies, with the general conclusion being that most companies are driven to disclose information about their CG practices by the desire to improve their reputation in the environment in which they operate, and thus their legitimacy (Melis et al., 2015).

In conclusion, the study employs the legitimacy theory to gain a more comprehensive picture and deeper understanding of CG and accountability practices within Libyan listed companies. Legitimacy theory was considered appropriate because the LSM and indeed the concept of CG itself are still becoming established in the Libyan environment. Under the LCGC (2007), Libyan listed companies are required to disclose in their financial statements brief details of the CG mechanisms they have implemented, which have not been implemented, and the reasons for noncompliance. By complying with this requirement, listed companies can reassure all relevant stakeholders that their interests are being protected, thereby enhancing their legitimacy and reputation (Melis et al., 2015). Furthermore, as more listed companies signal their compliance with these CG practices, the practices themselves also gain in legitimacy.

\section{RESEARCH METHOD}

This study is qualitative in nature. Creswell (2014) emphasizes the ability of qualitative research to capture people's experience of phenomena; to capture and describe phenomena in context, and to explain why phenomena occur. Data may be collected using a range of qualitative methods, such as observation, interviews and case studies. The most widely used of these is the interview, as it offers numerous advantages to the researcher. Qualitative interviews are commonly employed in the social sciences (including accounting and finance) to enhance the reliability and validity of the research process. They are considered particularly appropriate in cases where the information being sought is highly confidential or complicated (Hussey \& Hussey, 1997), but in all cases, they are invaluable in helping the researcher gain a rich insight into interviewees' background, experiences, views, aspirations, values, feelings, and attitudes (Bless et al., 2013)

Qualitative interviews may be structured or semi-structured. This flexibility makes them especially useful in exploratory research, where semi-structured interviews can be used to investigate not only "how" and "what", but also "why" research questions (Saunders et al., 2009). In semi-structured interviews, certain questions and themes will remain constant from one interview to another, but the format can be modified as necessary to respond to interviewees' answers or to explore any emerging issues (Bryman, 2004). From the interviewee's perspective, the semi-structured format gives them the space to express their views freely and to speak from their own knowledge and experience (Saunders et al., 2009). For these reasons, semi-structured interviews are deemed important for acquiring an adequate explanation and understanding of relevant events, patterns, and behaviours, and for establishing a more precise picture of interviewees' perceptions (Bryman \& Bell, 2003).

This study employed semi-structured interviews in order to gain a more detailed insight into the respondents' views. The interviews offered an opportunity for direct contact with targeted individuals in the business environment, allowing the researchers to capture an in-depth picture of their practice and knowledge. They were particularly appropriate for this study as many stakeholders in developing countries such as Libya are reluctant to disclose details of their experience in terms of CG and accountability in written surveys.

Twenty interviews were conducted with a wide variety of relevant stakeholders during the months of July and August 2015. The interviews were conducted in two main cities, namely Tripoli (at the LSM) and Misurata. Interviewees were chosen on the basis of their involvement with CG and accountability, their academic qualifications and their experience of working in or with Libyan listed companies. Table 1 shows that the stakeholders were classified into two groups based on the nature of their roles. These were the internal stakeholders group (ISG) and the external stakeholders group (ESG). 
Table 1. Interviewees' coding and characteristics

\begin{tabular}{|c|c|c|c|c|c|c|}
\hline No. & Code & Position & Sector & Qualification & Experience & Duration \\
\hline \multicolumn{7}{|c|}{ Group 1: Internal stakeholders group (ISG) } \\
\hline 1. & BD1 & Non-Executive Chairman & Banking Sector & Ph.D. in Accounting & 35 Years & 36 minutes \\
\hline 2. & BD2 & Executive Chairman & Industrial Sector & Ph.D. in Accounting & 30 Years & 44 minutes \\
\hline 3. & BD3 & Executive Chairman & $\begin{array}{l}\text { Financial Service } \\
\text { Sector }\end{array}$ & Ph.D. in Finance & 8 Years & 57 minutes \\
\hline 4. & BD4 & Chair of Audit Committee & Banking Sector & Ph.D. in Accounting & 35 Years & 35 minutes \\
\hline 5. & BD5 & Executive Board Member & Banking Sector & MSc in Accounting & 37 Years & $\begin{array}{l}1 \text { hour } 7 \\
\text { minutes }\end{array}$ \\
\hline 6. & BD6 & Non-Executive Board Member & Insurance Sector & BA in Management & 40 Years & 39 minutes \\
\hline 7. & BD7 & Executive Board Member & Investment Sector & Ph.D. in Accounting & 35 Years & 30 minutes \\
\hline 8. & BD8 & Executive Board Member & Banking Sector & Ph.D. in Management & 17 Years & 47 minutes \\
\hline 9. & EM1 & Chief Executive Officer (CEO) & Banking Sector & MSc in Accounting & 30 Years & $\begin{array}{l}1 \text { hour } 28 \\
\text { minutes }\end{array}$ \\
\hline 10. & EM2 & Chief of Trading Management & $\begin{array}{l}\text { Financial Service } \\
\text { Sector }\end{array}$ & MSc in Finance & 8 Years & $\begin{array}{l}1 \text { hour } 10 \\
\text { minutes }\end{array}$ \\
\hline 11. & EM3 & $\begin{array}{l}\text { Chief of Investment } \\
\text { Management }\end{array}$ & Investment Sector & Ph.D. in Accounting & 12 Years & 29 minutes \\
\hline 12. & EM4 & $\begin{array}{c}\text { Head of Internal Audit } \\
\text { Management }\end{array}$ & Service Sector & Ph.D. in Accounting & 28 Years & $\begin{array}{l}1 \text { hour } 28 \\
\text { minutes }\end{array}$ \\
\hline \multicolumn{7}{|c|}{ Group 2: External stakeholders group (ESG) } \\
\hline 13. & RE1 & Regulator & LSMA & Ph.D. in Accounting & 15 Years & 32 minutes \\
\hline 14. & RE2 & Regulator & $\begin{array}{c}\text { Ministry of } \\
\text { Economic Affairs }\end{array}$ & Ph.D. in Management & 12 Years & 47 minutes \\
\hline 15. & RE3 & External Auditor & Private Sector & Ph.D. in Accounting & 30 Years & $\begin{array}{l}1 \text { hour } 10 \\
\text { minutes }\end{array}$ \\
\hline 16. & RE4 & External Auditor & Private Sector & Ph.D. in Accounting & 33 Years & $\begin{array}{l}1 \text { hour } 13 \\
\text { minutes }\end{array}$ \\
\hline 17. & OS1 & Financial Consultant & $\begin{array}{c}\text { Financial Service } \\
\text { Sector }\end{array}$ & MSc in Management & 37 Years & 54 minutes \\
\hline 18. & OS2 & Individual Investor & Private Sector & Ph.D. in Management & 8 Years & $\begin{array}{l}1 \text { hour } 11 \\
\text { minutes }\end{array}$ \\
\hline 19. & OS3 & Academic & Education Sector & Ph.D. in Accounting & 15 Years & $\begin{array}{l}1 \text { hour } 9 \\
\text { minutes }\end{array}$ \\
\hline 20. & OS4 & Broker & Private Sector & MSc in Marketing & 10 Years & 33 minutes \\
\hline
\end{tabular}

There is no standardized approach to qualitative data analysis (Collis \& Hussey, 2009; Saunders et al., 2009). In this case, thematic analysis was applied as it was felt to be the most suitable for answering the research questions. A number of accounting studies have employed thematic analysis to analyze qualitative data gathered from semistructured interviews, including those by Vaismoradi et al. (2013), Ferdous (2012) and Braun and Clarke (2006). Ghauri and Gronhaug (2010) indicate that qualitative data analysis software is helpful where there is a large amount of data that require coding, linking and explaining. Several such programs are available, but as only 20 interviews were conducted in this study and the amount of qualitative data generated was manageable, coding was done manually.

\section{FINDINGS AND DISCUSSION}

CG mechanisms such as the BoD, disclosure and transparency, internal and external auditing and shareholder rights are the pillars on which the governance system is built. Accordingly, the two stakeholder groups were asked for their views on the current level of commitment being shown to these mechanisms within Libyan listed companies: To what extent are Libyan listed companies committed to implementing CG mechanisms and accountability?

The BoD is one of the key internal CG mechanisms (especially in emerging markets) ensuring that the interests of shareholders and managers are aligned and that management teams are operating effectively. All ISG and ESG interviewees confirmed that boards in Libyan listed companies have no fewer than three members and no more than eleven, the majority of whom are nonexecutive, as stipulated by the LCGC (2007). This was borne out in their descriptions of their own boards, which varied in size from company to company, depending on the type and volume of activity, but which were made up mostly of nonexecutives. For example, one board chairman explained that in his company the board:

Consists of seven members including the chairman of the board and three control members, the majority of whom are nonexecutive members, as well as independent members representing one-third of the board (BD3).

From the point of view of $C G$, this adherence to the board size requirement is encouraging. Nam and Lum's (2005) finding that the most efficient board size for CG purposes is fewer than twelve members seems to support the LCGC's eleven member maximum, though the findings of other authors suggest that boards at the top end of this scale may be more effective in their oversight role than their smaller counterparts (Al-Mosharrafa, 2015). This is because boards with ten or eleven members are more likely to encompass a wider range of skills, allowing them to make better decisions and monitor CEO performance more closely (Al-Matari et al., 2012; Al-Janadi et al., 2013). Muniandy and Hillier (2014) and El-Faitouri (2014) argue that appointing a combination of executive and non-executive directors minimizes the probability that the decision-making process will be dominated by one person or group within the board. The presence of independent members will also strengthen the board's ability to monitor and influence senior 
management (Al-Sahafi et al., 2015). Lemonakis et al. (2018) indicate that having NEDs can help boards be more independent, efficient and effective. INEDs are seen as a sign of CG quality; Braswell et al. (2012), for example, claim that the presence of INEDs indicates strong CG mechanisms and that boards with a high proportion of INEDs are more likely to support managers by routinely monitoring their activities.

On the subject of how board members are appointed, seven ISG and five ESG interviewees asserted that it is the responsibility of the general assembly to select and appoint board members according to pre-set technical and professional criteria. In state-owned banks, however, the job of selection may fall to the CBL, as explained by one CEO:

The selection and appointing of board members in the bank is done by the CBL, as it owns the largest percentage of shares (84\%). The CBL takes into account specific conditions for selecting the board of directors. The most important are technical and practical efficiency, specialist knowledge and experience at the top of the banking field (EM1).

Two ISG and three ESG interviewees argued that it would be unfair to ignore the fact that some board members within listed companies have been appointed out of nepotism or favouritism, because they have personal or tribal connections with members of the general assembly. One interviewee declared that:

In practice, there is no doubt that favours and personal relationships play a significant role in the selection of some board members within Libyan listed companies, although experience and efficiency also play a part. But the unfair selection process means that executive directors are not held accountable for any deficiencies in their implementation of CG (OS3).

The interview outcomes indicated that general assemblies in Libyan listed companies are practically committed to the LCGC's requirements that they, as the shareholders' representatives, should be solely responsible for appointing board members and that these board members should be selected according to pre-set criteria for technical knowledge and experience, as set down in the code. The result thus appears consistent with Mallin's (2013) finding that the criteria for selecting and appointing board members are typically stipulated in national CG codes and regulations. However, evidence also emerged that these criteria are sometimes abandoned in favour of personal relationships.

All ISG and ESG interviewees declared that the duties and responsibilities of the BoD are precisely defined by Libyan listed companies. A monitor from the LSMA asserted that:

I can honestly say there is a clear determination of duties and responsibilities in Libyan listed companies, because on the one hand, all listed companies have their establishment decision and statute, which define the duties and responsibilities of the board of directors, and on the other hand, the LCGC, whether issued by the $L S M$ or the CBL, also determines perfectly the duties and responsibilities of the board of directors within listed companies (RE1).
The ISG and ESG respondents echoed the Cadbury Report (1992), the OECD (2004), the UK Combined Code (2006), the UK CG Code (2016), Monks and Minow (2008) and Al-Matari et al. (2012) in suggesting that the main duties and responsibilities of the board are to set the direction of the company through targeted aims, policies, plans and strategies over the short and long term. The results are also in line with Mallin's (2013) argument that the primary role of the BoD is to set the company's objectives and monitor its progress towards achieving its goals, and with Clarke's (2007) finding that the board's three main roles are control, strategic and institutional. The findings provide evidence that boards in Libyan listed companies are carrying out their duties in accordance with internal regulations and laws, as well as the stipulations of the LCGC (2007). Furthermore, the stakeholder groups were broadly satisfied that board members are devoting sufficient time and effort to discharge these duties and responsibilities properly.

Disclosure and transparency are considered crucial principles within the CG system; numerous authors (Solomon, 2013; Monks \& Minow, 2004) have stressed their importance as an indicator of good CG. However, when the interviewees were asked whether the level of disclosure and transparency within Libyan listed companies is adequate, eight ISG and five ESG interviewees claimed that it is merely satisfactory. Six ISG and two ESG interviewees argued that this is because current disclosure and transparency practices are designed only to meet local, not international, requirements. One executive board member asserted that:

The level of disclosure and transparency in our listed companies is generally satisfactory by local standards, such as the requirement for annual reports to disclose both financial and non-financial data, details of board meetings and the names of committee members. However, compared to international requirements, and to [the level of] disclosure in similar emerging markets, it needs improvement (BD7).

The other four ISG interviewees perceived disclosure and transparency practices within Libyan listed companies to be inadequate for a range of reasons, including the lack of accountability mechanisms in the Libyan environment and the weakness of the professional culture. One executive chairman (BD2) attributed the low level of disclosure and transparency to the lack of Libyan Accounting Standards, while an executive manager cited a lack of understanding on the part of boards:

There is an obvious weakness in companies' transparency because board members are the only parties who have the right to be informed about the company's important information due to their position, but unfortunately, some board members do not have a clear understanding of the meaning of disclosure and transparency (EM2).

Three of the ESG interviewees were highly critical of the level of disclosure and transparency within listed companies, describing it as very low. One external auditor ascribed this to "the lack of awareness among executive directors concerning the right meaning of disclosure and transparency" (RE4). At the macro level, one regulator pointed to the lack 
of an oversight body in Libya to determine exactly what should be disclosed, as well as weak public awareness and lack of interest among stakeholders. The result is that Libyan listed companies disclose only what they deem appropriate to comply with the law (i.e. the income statement, cash flow statement and statement of financial position) while regarding the disclosure of anything else as voluntary.

When ISG and ESG interviewees were asked whether Libyan listed companies disclose their CG practices in their annual reports, seven of the ISG and five of the ESG indicated that listed companies are in fact only required to offer a brief summary of which CG principles have been implemented and which have not, and the reasons why not. One individual investor explained:

There is disclosure in the financial reports on the extent of CG practices in Libyan listed companies, especially in the companies that belong to the banking sector, because all banks already adhere to CG mechanisms according to the requirements of the CBL. Other Libyan listed companies do not disclose CG practices in their financial reports in detail, other than to disclose what has been applied and what has not been applied in terms of CG mechanisms (OS2).

The findings from the interviews confirm that the level of disclosure and transparency in Libyan listed companies is barely satisfactory for a range of reasons, most of which originate in a general lack of interest in disclosure among stakeholders. The interviewees argued that disclosure requirements in Libya lag behind those even of other emerging markets, with the result that listed companies concentrate their disclosure on basic information such as the income statement and statement of financial position. Thirteen interviewees (a mixture of internal and external stakeholders) argued that this is because current disclosure and transparency practices are designed only to meet local, not international, requirements. Blame was placed on the inertia of the Libyan Association for Accountants and Auditors (LAAA), which could play a much greater role in lobbying for disclosure and transparency requirements to be strengthened, but the interviewees also criticized the weakness of Libya's regulatory and oversight bodies in general for failing to determine exactly what should be disclosed. A few attributed the poor disclosure levels to the lack of accountability mechanisms in the Libyan environment, citing the lack of Libyan Accounting Standards and the non-adoption of international standards. These interviewees followed Black et al. (2008) in seeing a link between the low levels of financial disclosure and the absence of international accounting standards.

When asked whether the duties and responsibilities of the internal audit are clearly defined, almost all of the interviewees pointed out that these are defined not just in job descriptions and company statutes but also in law - specifically, LCL No. 23 (2010) and the LSM's LCGC. BD2, an executive chairman, explained that the internal audit's tasks include "monitoring compliance with laws and regulations, as well as financial and administrative (comprehensive) monitoring within the company". However, given the broadness of this description, it is perhaps not surprising that four interviewees called for the internal audit's duties and responsibilities to be set out in more specific terms. One executive manager observed that the lack of a clearly defined and directed focus can have negative consequences:

Although these duties and responsibilities are defined, they lack detail. Furthermore, because the scope of the internal audit is more comprehensive and also covers administrative and technical matters, it ends up ignoring the routine work (EM4).

Almost all ISG and ESG interviewees were generally satisfied with how internal auditors in Libyan listed companies discharge their duties, though a few interviewees identified some shortcomings. The most critical was the deputy minister from the Ministry of Economic Affairs, who listed several problems and explained how perceived inadequacies within the internal audit function affect shareholders:

There are a number of reasons for this: firstly, the insufficiency of some internal auditors who are engaged in the work of internal audit at these listed companies. Secondly, in practice, internal audit departments are dominated and influenced by executive directors within these companies. Thirdly, as a result of the above points, general assemblies tend to ignore the internal auditor's report in their meetings, instead of depending on the external auditor's report because it is independent and far from the influence of the board of directors in the company. Finally, the internal audit function is generally limited to the financial audit, despite the fact that its formal duties also include an administrative and technical audit (RE2).

The interviewees echoed Al-Matari et al. (2014) and Al-Matarneh (2011) in seeing the internal audit (in principle, at least) as an important pillar within the company's CG structure. They also seemed to support Hutchinson \& Zain's (2009) view of the internal audit as the main mechanism supporting the BoD and the audit committee in their job of ensuring the credibility of the financial reporting process.

However, when asked whether internal control systems in Libyan listed companies are efficient, just four ISG and three ESG interviewees believed them to be generally effective. Seven ISG and five ESG interviewees regarded them as inadequate, mainly because internal and external auditors alike fail to monitor these systems with sufficient rigour. One financial consultant asserted that:

External auditors repeatedly note in their reports that internal control systems are weak because no one is monitoring whether the laws and regulations are being enforced. These laws and regulations would strengthen the internal control systems in Libyan listed companies if they were enforced effectively (OS1).

This seems inconsistent with Eighme and Cashell's (2002) claim that the internal audit plays a significant role in enhancing the efficiency of the company's internal control system, and with the Cadbury Report's (1992) view of the internal audit mechanism as an effective tool for monitoring controls and measures within a company.

Discussing how external auditors are appointed, eleven ISG and five ESG interviewees asserted that listed companies have strict selection 
criteria. One individual investor described the criteria employed by his company:

The LSM states that any external auditor registered in the market and according to the conditions for registration shall have the right to review financial statements for Libyan listed companies. This mechanism was imposed by the LSM to limit the external audit function to the professionally competent, as only those competent in the field can be registered. Apart from registration with the LSM, the criteria also cover technical proficiency, experience, fees and the duration of the audit. External auditors then submit their tenders to the general assembly, which evaluates their files against these criteria (OS2).

The consensus among both ISG and ESG interviewees was that listed companies appoint LSMregistered external auditors to review their financial statements, indicating that stakeholders generally have confidence in the integrity of the selection process. It was repeatedly emphasized that listed companies follow a set of criteria when selecting external auditors. These criteria were imposed by the LSM to ensure that only the technically proficient and experienced can be appointed, but they are also an assurance of the auditor's independence. The link between independence and proficiency is made explicit in the OECD's (2004) recommendation that the auditor should be "independent, competent and qualified". The Cadbury Report (1992) asserts that the external audit is the cornerstone of a company's CG because it offers an objective consideration of the manner in which the financial statements are prepared and presented to users.

The importance of protecting shareholder rights is highlighted in many CG codes and principles, including those issued by the OECD in 2004 (Shanikat \& Abbadi, 2011). When the participants in this study were asked to say to what extent they thought the rights of shareholders are protected and respected in Libyan listed companies, seven ISG and two ESG interviewees asserted that these rights are guaranteed under the law and in practice. One executive board member declared that:

The LCGC (2007) refers clearly to shareholders rights. Further to this, Libyan Commercial Law No. 23 (2010) stipulates that shareholders have the right to review the minutes of meetings of the general assembly and that they must receive their invitation to attend the general assembly meeting no less than fifteen days beforehand so they can study the items on the agenda. This law states that shareholders have the right to receive the annualized dividend according to a specific policy. Shareholders have the right to vote on appointments to the board of directors and on any decisions in which they have an interest, and to cumulative voting according to their share of the capital. In practice, all the aforementioned shareholders' rights are guaranteed and protected by Libyan listed companies (BD8).

However, the remaining five ISG and six ESG interviewees argued that while all shareholder rights are absolutely protected in terms of company law and regulation, some listed companies fail to respect these rights in practice. One executive board member cited problems with dividend distribution, in particular, explaining that some Libyan listed companies in the public sector "do not care about setting clear policy regarding the distribution of dividends" (BD5). One regulator also claimed that:

In fact, some boards in Libyan listed companies have a hold over the general assembly. Consequently, their decisions are biased and not impartial, which leads to the erosion of minority shareholders' rights. For example, dividends are withheld for the purposes of investment without compelling reason or explanation of where specifically this investment is going. Furthermore, the unreliability of the media in the Libyan environment in general and within Libyan listed companies in particular means that there are often delays in informing the members of the general assembly (especially the minority shareholders) about the date of general assembly meetings (RE2).

The ESG interviewees were a lot less positive than the ISG interviewees that shareholder rights are being protected and respected by companies, both legally and in practice, with some suggesting that minority shareholders tend to suffer because of the ownership structure in Libyan listed companies, most of which are state-owned. This finding echoes the findings of studies conducted in other developing economies. Alkahtani (2015), for instance, found that in Saudi Arabia, where the concentrated ownership model dominates, minority shareholders may not have the power to exercise their rights, even though provisions exist within the country's legislation to challenge violations of these rights. Solomon (2010) found Jordan to have an insider-dominated CG system, a stock exchange lacking in accountability and transparency, and no consideration for minority shareholders' rights, while Mallin (2013) found that minority shareholders' rights in Malaysia suffer under pressure from majority shareholders seeking to retain company control. Tackling the inequality between majority and minority shareholders in Libyan listed companies is important both for improving company-minority shareholder relations and for the LSM as a whole, but the problem must first be addressed by the country's regulatory and monitoring authorities.

The literature illustrates that the factors influencing CG practice vary from country to country. Accordingly, the second question in this study (What factors inhibit CG and accountability practices in Libyan listed companies?) sought to investigate which factors internal and external stakeholders in this study perceived as having the most influence in the Libyan environment.

Both ISG and ESG interviewees overwhelmingly agreed that the factor having the greatest impact on CG and accountability practices in Libyan listed companies is the lack of knowledge and awareness about the concept of CG at all company levels. One board chairman (BD1) suggested that this may be because the CG culture has yet to become established in most Libyan institutions, either at the top or bottom of the hierarchy. He also pointed to a lack of training programmes for members of the general assembly, BoDs and executive directors (even when they are directly concerned with CG practice), explaining that general assembly members and board members rarely participate in 
conferences, seminars or workshops on CG. This finding is consistent with Iswaissi and Falahati's (2017) conclusion that there is lack of adequate training on CG practices within Libyan commercial banks, which account for the majority of listed companies in the country. The finding serves as further evidence that the Union of Arab Banks (UAB, 2007) is right to press for extensive CG training for all relevant parties in the Arab banking sector. It is also in line with the findings of Braendle et al. (2013), who assert that the foremost barrier to the improvement of CG practice in the Iranian environment is the lack of knowledge about CG.

Eight ISG interviewees highlighted the weakness of the legislative environment as the second most influential factor on the grounds that this underlies the generally poor performance of Libya's supervisory and regulatory bodies. One interviewee argued that:

There are many causes, including the failure to develop laws and legislation suited to the principles of $C G$, although they are in line with the socialist system which was previously adopted by the Libyan state. Also, the weak performance of the regulatory and monitoring bodies in the Libyan environment and the LSMA in particular (BD8).

Six ESG interviewees identified the weakness of the legislative environment as the second most significant factor affecting CG and accountability practices. One regulator argued that:

Confusion accompanied the determination of our economic identity under the former regime, and this led to the creation of a culture in which laws and regulations were not seen as fixed. This has made it more difficult to enforce the laws and regulations that support CG practices and accountability in the Libyan environment (RE2).

These findings support Okpara's (2011) argument that an inadequate legal system and lack of adherence to the regulatory framework are the main challenges to implementing CG in developing countries. They also support Alajlan's (2004) finding that Arab markets, in general, are poorly regulated and that the laws governing listed companies are not consistently enforced. Brahim and Nourredines (2017), in their study of Algerian companies, offer a similar example of a legislative environment that is doing little to encourage CG practice.

The lack of accountability was identified as another significant factor, with seven ISG interviewees explaining that companies are currently not accountable for their failure to implement CG. One audit committee chairman explained that:

This lack of accountability is partly legal in origin (existing legislation is incompatible in some respects with the requirements of $C G$, and there are no laws to enforce compliance), but social factors also play a part (BD4).

Four ESG interviewees also observed that Libyan listed companies are not currently accountable for any shortcomings in their implementation of CG. One external auditor (RE3) attributed this to the poor performance of the monitoring and regulatory bodies, who fail to punish companies violating the regulations and abuse the powers conferred upon them. The importance of enforcement is emphasized in a number of other studies, including those by Okike (2007) and Wong (2009). These authors point to other governments (e.g. Nigeria) that have demonstrated a determination to improve $C G$ by issuing new corporate legislation and CG codes for listed companies, but who have largely failed in their aim because enforcement of this legislation has been weak. The view that the enforcement of a law is at least as important as its original enactment is repeated by Berglöf and Claessens (2004), who argue that law enforcement is as central to achieving effective protection for all shareholders as law creation. Similarly, La Porta et al. (1999) conclude that both the presence and the enforcement of laws and regulations protecting minority shareholders are fundamental determinants in the development of stock markets. Both ISG and ESG interviewees echoed Braendle et al. (2013) in identifying weak accountability mechanisms as a key obstacle to the development of CG practice. Writing about the Iranian context, Braendle et al. explain that these mechanisms are not widely understood, nor is the concept of accountability itself encouraged, in Iran's business environment.

\section{CONCLUSION}

The interview findings provide evidence that Libyan listed companies generally comply with the LCGC's (2007) requirements regarding the BoD mechanism. The interviewees unanimously confirmed that boards in Libyan listed companies have between three and eleven members, the majority of whom are non-executive, as stipulated by the LCGC. The majority of both groups asserted that the general assembly is responsible for selecting and appointing board members according to pre-set technical and professional criteria. The results provide evidence that boards in Libyan listed companies are generally carrying out their duties and responsibilities in accordance with internal regulations and laws.

On the issue of disclosure and transparency, both ISG and ESG interviewees perceived the level of disclosure and transparency in Libyan listed companies as barely satisfactory. They complained that disclosure requirements in Libya lag behind those even of other emerging markets, with the result that listed companies limit their disclosure to basic financial information such as the income statement and statement of financial position. In terms of CG disclosure specifically, interviewees pointed out that under the LCGC (2007), Libyan listed companies are only required to disclose which CG principles have been implemented and which have not, and the reasons why not. The view was also expressed that at present, disclosure and transparency practices in Libya are designed only to meet local requirements.

ISG and ESG interviewees alike were critical of the role currently being played by the internal and external audit and were unconvinced of the effectiveness of internal control systems in Libyan listed companies. The evidence suggests that while these companies have taken practical steps to comply with the LCGC's requirements regarding the internal and external audit mechanisms, they are not committed enough to ensure that these mechanisms are consistently monitored and enforced. 
There was less of a consensus on the issue of shareholder rights; although the majority of ISG interviewees felt that shareholder rights are protected and respected by companies, the ESG interviewees were less positive, with several claiming that majority shareholders enjoy much greater protection, both legally and in practice, than minority shareholders.

Overall, the interview findings demonstrate that Libyan listed companies are to some extent committed to implementing CG mechanisms, but that CG and accountability are still relatively novel concepts, and there remain significant weaknesses in terms of practice. Listed companies' commitment is most evident in their adherence to the LCGC's (2007) requirements regarding the BoD mechanism, but they are also engaging with the requirement for disclosure and transparency, albeit to local rather than international standards. Listed companies have also taken practical steps towards meeting the LCGC's requirements regarding the internal and external audit mechanisms, but the general view among stakeholders is that these mechanisms are currently not robust enough to ensure strong internal control systems. Finally, in terms of the shareholders' rights mechanism, majority shareholders are seen to enjoy much greater protection, both legally and in practice, than minority shareholders.

The interviews yielded rich, complex insights into what internal and external stakeholders perceived as the main factors influencing CG and accountability practice in Libya's listed companies. The general consensus across both groups was that the most significant factor inhibiting the advance of CG is the lack of knowledge and awareness about the concept at all company levels. This is followed by the weakness of the Libyan legislative environment and the lack of accountability within listed companies. Collectively, these are creating a poor environment for $\mathrm{CG}$ and accountability in Libya.

Although the current study makes a valuable contribution to knowledge by investigating the extent to which CG mechanisms and accountability are being implemented in Libyan listed companies, it should be acknowledged that, as with any other study in social research, it has certain limitations. The first is the generalisability of the results. Caution is necessary here; since just 20 individuals were interviewed, it is quite possible that the findings might not accurately reflect the full range of views held by stakeholders in the Libyan environment. Furthermore, although pains were taken to gather data from the broadest possible range of stakeholders, ensuring that each stakeholder group was adequately represented was made more difficult by the fact that many of the target population (especially general assembly members, board members, and sub-committee members) were unavailable to participate; many work part-time and do not have permanent offices in their companies, while others were too busy to schedule meetings and interviews.

Comparatively few studies have explored CG in Libya, making it a vital area for future research. This study investigates Libyan listed companies' compliance with CG mechanisms and accountability. Some of the key CG mechanisms should be examined individually and in-depth to increase understanding of their significance in the Libyan environment. Further research is also recommended to illuminate how disclosure levels influence accountability practices in Libyan listed companies.

\section{REFERENCES}

1. Abdullah, S. (2016). Corporate governance mechanisms and the performance of Malaysian listed firms. Corporate Ownership \& Control, 14(1-2), 384-398. http://doi.org/10.22495/cocv14i1c2p10

2. Abdulsaleh, A. (2014). Corporate governance role of audit committees in the banking sector: Evidence from Libya. International Journal of Social Management, Economics and Business Engineering, 8(2), 592-597. Retrieved from https://waset.org/publications/9997835/corporate-governance-role-of-audit-committees-in-the-bankingsector-evidence-from-libya

3. Abdulsamad, A., Yusoff, W., \& Lasyoud, A. (2018). The influence of the board of directors' characteristics on firm performance: Evidence from Malaysian public listed. Corporate Governance and Sustainability Review, 2(1), 6-13. http://doi.org/10.22495/cgsrv2ilp1

4. Ahmad, N., Othman, R., Othman, R., \& Jusoff, K. (2009). The effectiveness of internal audit in Malaysian public sector. Journal of Modern Accounting and Auditing, 5(9), 53-62. Retrieved from https://www.researchgate.net/profile/Radiah_Othman/publication/253237168_The_Effectiveness_of_Internal_ Audit_in_Malaysian_Public_Sector/links/00b7d52ec67ea63e10000000/The-Effectiveness-of-Internal-Audit-inMalaysian-Public-Sector.pdf

5. Ahmad, S., \& Gao, S. (2004). Changes, problems and challenges of accounting education in Libya. Accounting Education, 13(3), 365-390. https://doi.org/10.1080/0963928042000273825

6. Ahunwan, B. (2002). Corporate governance in Nigeria. Journal of Business Ethics, 37(3), $269-287$. https://doi.org/10.1023/A:1015212332653

7. Al-Baidhani, A. (2015). The effects of corporate governance on bank performance: Evidence from the Arabian Peninsula. http://doi.org/10.2139/ssrn.2284814

8. Al-Gharaibeh, M., Zurigat, Z., \& Al-Harahsheh, K. (2013). The effect of ownership structure on dividends policy in Jordanian companies. Interdisciplinary Journal of Contemporary Research in Business, 4(9), 769-796. Retrieved from https://journal-archieves27.webs.com/769-796.pdf

9. Al-Haddad, W., Alzurqan, S., \& Al-Sufy, F. (2011). The effect of corporate governance on the performance of Jordanian industrial companies: An empirical study on Amman Stock Exchange. International Journal of Humanities and Social Science, 1(4), 55-69. Retrieved from http://www.ijhssnet.com/journals/ Vol._1_No._4;_April_2011/8.pdf

10. Al-Janadi, Y., Rahman, R., \& Haji Omar, N. (2013). Corporate governance mechanisms and voluntary disclosure in Saudi Arabia. Research Journal of Finance and Accounting, 4(4), 25-35. Retrieved from https://pdfs.semanticscholar.org/78a9/b2f1c40016eb14c19f092c52e919c18f5065.pdf 
11. Al-Manaseer, M., Al-Hindawi, R., Al-Dahiyat, M., \& Sartawi, I. (2012). The impact of corporate governance on the performance of Jordanian banks. European Journal of Scientific Research, 67(3), 349-359. Retrieved from https://www.researchgate.net/publication/267943365_The_Impact_of_Corporate_Governance_on_the_Perform ance_of_Jordanian_Banks

12. Al-Matari, E., Al-Swidi, A., \& Fadzil, B. (2014). The effect of the internal audit and firm performance : A proposed research framework. International Review of Management and Marketing, 4(1), 34-41. Retrieved from https://dergipark.org.tr/download/article-file/366666

13. Al-Matari, Y., Al-Swidi, A., Bt Fadzil, F., \& Al-Matari, E. (2012). Board of directors, audit committee characteristics and performance of Saudi Arabia listed companies. International Review of Management and Marketing, 2(4), 241-251. Retrieved from https://dergipark.org.tr/download/article-file/366637

14. Al-Matari, Y., Al-Swidi, A., \& Fadzil, F. (2012). Corporate governance and performance of Saudi Arabia listed companies. British Journal of Arts \& Social Sciences, 9(1), 1-30. Retrieved from http://repo.uum.edu.my/15435/

15. Al-Matarneh, G. (2011). The extent of adherence of Jordanian auditors in implementing the international standard on auditing ISA 700. International Management Review, 7(1), 22. Retrieved from https://www.questia.com/library/journal/1P3-2343973351/the-extent-of-adherence-of-jordanian-auditors-inimplementing

16. Al-Mosharrafa, R. (2015). Relative consequences due to absence of corporate governance in nationalized and private commercial banks in Bangladesh. Journal of Economics and International Finance, 7(2), 42-50. https://doi.org/10.5897/JEIF2014.0633

17. Alqudah, A., \& Azzam, M. (2019). The impact of board of directors characteristics on banks performance: Evidence from Jordan, Academy of Accounting and Financial Studies Journal, 23(2), 1-16. Retrieved from https://www.researchgate.net/publication/331984927_THE_IMPACT_OF_BOARD_OF_DIRECTORS_CHARACTERI STICS_ON_BANKS_PERFORMANCE_EVIDENCE_FROM_JORDAN

18. Al-Sahafi, A., Rodrigs, M., \& Barnes, L. (2015). Does corporate governance affect financial performance in the banking sector? International Journal of Economics, Commerce and Management, 3(3), 1-26. Retrieved from http://ijecm.co.uk/wp-content/uploads/2015/03/333.pdf

19. Al-Sawalqa, F. (2014). Corporate governance mechanisms and voluntary disclosure compliance: The case of banks in Jordan. International Journal of Academic Research in Accounting, Finance and Management Sciences, 4(2), 369-384. https://doi.org/10.6007/IJARAFMS/v4-i2/935

20. Al-Thuneibal, A., Issa, R., \& Baker, R. (2011). Do audit tenure and firm size contribute to audit quality: Empirical evidence from Jordan. Managerial Auditing Journal, 26(4), 317-334. https://doi.org/10.1108/ 02686901111124648

21. Al Daoud, K., Ismail, K., \& Lode, N. (2015). The impact of internal corporate governance on the timeliness of financial reports of Jordanian firms: Evidence using audit and management report lags. Mediterranean Journal of Social Sciences, 6(1), 430-442. http:// doi.org/10.5901/mjss.2015.v6n1p430

22. Alabede, J. (2012). The role, compromise and problems of the external auditor in corporate governance. Research Journal of Finance and Accounting, 3(9), 114-126. Retrieved from https:/www.iiste.org/Journals/ index.php/RJFA/article/view/3157

23. Alajlan, W. (2004). Ownership patterns and the Saudi Market. In M. Hirschey, K. John, \& A. K. Makhija (Eds.), Corporate Governance (Advances in Financial Economics, 9), (pp. 161-186). Emerald Group Publishing Limited. https://doi.org/10.1016/S1569-3732(04)09007-3

24. Alkahtani, A. (2015). The influence of corporate governance on protecting minority shareholders' rights in the Saudi stock market: A comparative study (PhD thesis, University of Westminster). Retrieved from https://pdfs.semanticscholar.org/d737/bf518842e2f12b9b3d128465304b67041c69.pdf

25. Allen, F. (2005). Corporate governance in emerging economies. Oxford Review of Economic Policy, 21(2), 164177. https://doi.org/10.1093/oxrep/gri010

26. Alshehri, A. (2012). An investigation into the evolution of corporate governance and accountability in Saudi Arabia (PhD thesis, University of London, Kings College). Retrieved from https://ethos.bl.uk/ OrderDetails.do?uin=uk.bl.ethos. 572506

27. Alzebana, A., \& Sawan, N. (2015). The impact of audit committee characteristics on the implementation of internal audit recommendations. Journal of International Accounting, Auditing and Taxation, 24, 61-71. https://doi.org/10.1016/j.intaccaudtax.2015.02.005

28. Andreasson, S. (2011). Understanding corporate governance reform in South Africa: Anglo-American divergence, the king reports, and hybridization. Business and Society, 50(4), 647-673. https://doi.org/10.1177/0007650309332205

29. Archambault, J., \& Archambault, M. (2003). A multinational test of determinants of corporate disclosure. The International Journal of Accounting, 38(2), 173-194. https://doi.org/10.1016/S0020-7063(03)00021-9

30. Atkins, J., Zakari, M., \& Elshahoubi, I. (2018). Implementing the board of directors' mechanism - An empirical study of the listed firms in Libya, Corporate Board: Role, Duties and Composition, 14(1), 22-33. http://doi.org/10.22495/cbv14ilart2

31. Baker, R., \& Owsen, M. (2002). Increasing the role of auditing in corporate governance. Critical Perspectives on Accounting, 13(5-6), 783-795. https://doi.org/10.1006/cpac.2002.0566

32. Bankewitz, M. (2016). Board advisory tasks: The importance to differentiate between functional and firmspecific advice. American Journal of Management, 16(1), 54-69. Retrieved from http://digitalcommons.www.nabusinesspress.com/AJM/BankewitzM_Web16_1_.pdf

33. Berglöf, E., \& Claessens, S. (2004). Enforcement and corporate governance (Policy Research Working Paper Series No. 3409). The World Bank. Retrieved from https://doi.org/10.1596/1813-9450-3409

34. Black, B., Gorga, É., \& Carvalho, D. (2008). An overview of Brazilian corporate governance. (Research Paper No. 101), Cornell Law Faculty Publications, 1-48. Retrieved from https://scholarship.law.cornell.edu/ lsrp_papers/101/

35. Bless, C., Higson-Smith, C., \& Sithole, S. (2013). Fundamentals of social research methods: An African perspective (5th ed). Cape Town: Juta and Company Ltd.

36. Braendle, U., Omidvar, A., \& Tehraninasr, A. (2013). On the specifics of corporate governance in Iran and the Middle East. Corporate Ownership \& Control, 10(3), 49-62. http://doi.org/10.22495/cocv10i3art5 
37. Brahim, Z., \& Nourredine, F. (2017). Corporate governance among small and medium size enterprises in Algeria: Impediments to the practice of corporate governance system. Asian Journal of Economic Modelling, 5(2), 154166. http://doi.org. 10.18488/journal.8.2017.52.154.166

38. Branco, M., \& Rodrigues, L. (2008). Factors influencing social responsibility disclosure by Portuguese companies. Journal of Business Ethics, 83(4), 685-701. https://doi.org/10.1007/s10551-007-9658-z

39. Braswell, M., Daniels, B., Landis, M., \& Chang, A. (2012). Characteristics of diligent audit committees. Journal of Business \& Economics Research, 10(4), 191-206. https://doi.org/10.19030/jber.v10i4.6895

40. Braun, V., \& Clarke, V. (2006). Using thematic analysis in psychology. Qualitative Research in Psychology, 3(2), 77-101. https://doi.org/10.1191/1478088706qp063oa

41. Brennan, N., \& Solomon, J. (2008). Corporate governance, accountability and mechanisms of accountability: An overview. Accounting, Auditing \& Accountability Journal, 21(7), 885-906. https://doi.org/10.1108/ 09513570810907401

42. Briano-Turrent, G., \& Rodríguez-Ariza, L. (2016). Corporate governance ratings on listed companies: An institutional perspective in Latin America. European Journal of Management and Business Economics, 25(2), 6375. https://doi.org/10.1016/j.redeen.2016.01.001

43. Bryman, A. (2004). Social research methods. Oxford: Oxford University Press.

44. Bryman, A., \& Bell, E. (2003). Business research methods. New York: Oxford University Press.

45. Bushman, R., Piotroski, J., \& Smith, A. (2004). What determines corporate transparency? Journal of Accounting Research, 42(2), 207-252. https://doi.org/10.1111/j.1475-679X.2004.00136.x

46. Cadbury Report. (1992). Report of the Audit Committee on the Financial Aspects of Corporate Governance: The Code of Best Practice. London. Retrieved from https://www.icaew.com/-/media/corporate/files/library/ subjects/corporate-governance/financial-aspects-of-corporate-governance.ashx?la=en

47. Certo, S., Daily, C., \& Dalton, D. (2001). Signaling firm value through board structure: An investigation of initial public offerings. Entrepreneurship Theory and Practice, 26(2), 33-50. https://doi.org/10.1177/ 104225870102600202

48. Chhaochharia, V., \& Laeven, L. (2009). Corporate governance norms and practices. Journal of Financial Intermediation, 18(3), 405-431. https://doi.org/10.1016/j.jfi.2008.10.001

49. Claessens, S., \& Yurtoglu, B. (2012). Corporate governance in emerging markets: A survey. Emerging Markets Review, 15, 1-77. https://doi.org/10.2139/ssrn.1988880

50. Clarke, T. (2007). International corporate governance: A comparative approach. Routledge. https://doi.org/10.4324/9780203300725

51. Collis, J, \& Hussey, R. (2009). Business research: A practical guide for undergraduate and postgraduate students. Basingstoke: Palgrave Macmillan.

52. Creswell, J. (2014). Research design. Oualitative, quantitative and mixed methods approaches. London: SAGE Publications. Retrieved from https://gul.gu.se/public/pp/public_file_archive/archive.html?publishedItemId= $42564721 \&$ courseId $=86421$ \&fileId $=42564716$

53. Dalwai, T., Basiruddin, R., Abdul Rasid, S., Kakabadse, N., \& Fleur, M. (2015). A critical review of relationship between corporate governance and firm performance: GCC banking sector perspective. Corporate Governance: The International Journal of Business in Society, 15(1), 18-30. https://doi.org/10.1108/CG-04-2013-0048

54. Daykin, T. (2006). The role of internal auditing in sustainable development and corporate social reporting. The Institute of Internal Auditors Research Foundation. Retrieved from https://na.theiia.org/aboutus/Public\%20Documents/Sawyer_Award_2006.pdf

55. Deegan, C. (2004). Financial accounting theory. Australia: McGraw-Hill Pty Ltd. Retrieved from https://www.academia.edu/38100065/FINANCIAL_ACCOUNTING_THEORY-_Deegan

56. Deegan, C., Rankin, M., \& Voght, P. (2000). Firms' disclosure reactions to major social incidents: Australian evidence. Accounting Forum, 24(1), 101-130. Retrieved from https:/www.researchgate.net/publication/ 227785164_Firms'_Disclosure_Reactions_to_Major_Social_Incidents_Australian_Evidence

57. Doski, S. (2015). The necessity of issuing a corporate governance code for the Kurdistan Region, Journal of Finance and Accounting, 18, 1-19. Retrieved from https://www.aabri.com/manuscripts/142059.pdf

58. Ebaid, I. (2011). Internal audit function: An exploratory study from Egyptian listed firms. International Journal of Law and Management, 53(2), 108-128. https://doi.org/10.1108/17542431111119397

59. Eighme, J., \& Cashell, J. (2002). Internal auditors' roles in overcoming the financial reporting crisis. Internal Auditing, 17(6), 3-10.

60. El-Faitouri, R. (2014). Board of directors and Tobin's Q: Evidence from UK firms. Journal of Finance and Accounting, 2(4), 82-99. http://doi.org/10.12691/jfa-2-4-2

61. Elshahoubi, I. (2019). An investigation into corporate governance (CG) and accountability practices: Evidence from Libyan listed companies ( $\mathrm{PhD}$ thesis, University of Reading).

62. Eulerich, M., Henseler, J., \& Köhler, A. (2017). The internal audit dilemma-the impact of executive directors versus audit committees on internal auditing work. Managerial Auditing Journal, 32(9), 854-878. https://doi.org/10.1108/MAJ-08-2016-1435

63. Fama, E., \& Jensen, M. (1983). Separation of ownership and control. The Journal of Law and Economics, 26(2), 301-325. https://doi.org/10.1086/467037

64. Faraj, S., \& El-Firjani, E. (2014). Challenges facing IASs/IFRS implementation by Libyan listed companies. Universal Journal of Accounting and Finance, 2(3), 57-63. http://doi.org/10.13189/ujaf.2014.020302

65. Ferdous, C. (2012). Compliance with codes of corporate governance in developing economies: The case of Bangladesh (PhD thesis, University of Birmingham). Retrieved from https://etheses.bham.ac.uk/id/eprint/ 3993/1/Ferdous13PhD_Redacted.pdf

66. Filatotchev, I., \& Nakajima, C. (2014). Corporate governance, responsible managerial behavior, and corporate social responsibility: Organizational efficiency versus organizational legitimacy? Academy of Management Perspectives, 28(3), 289-306. https://doi.org/10.5465/amp.2014.0014

67. Financial Reporting Council (2003). Combined Code on Corporate Governance. Retrieved from https://ecgi.global/sites/default/files//codes/documents/combined_code_final.pdf

68. Ghafran, C., \& O'Sullivan, N. (2017). The impact of audit committee expertise on audit quality: Evidence from UK audit fees. British Accounting Review, 49(6), 578-593. https://doi.org/10.1016/j.bar.2017.09.008 
69. Ghauri, P., \& Gronhaug, K. (2010). Research methods in business studies (4th ed). England: Financial Times Prentice Hall.

70. Gil, E., Hernandez, S., \& Perez, D. (2012). Internal audit and financial reporting in the Spanish banking industry. Managerial Auditing Journal, 27(8), 728-753. https://doi.org/10.1108/02686901211257028

71. Gray, A., \& Jenkins, B. (1993). Codes of accountability in the new public sector. Accounting, Auditing \& Accountability Journal, 6(3), 52-67. https://doi.org/10.1108/09513579310042560

72. Gray, R., Adams, C., \& Owen, D. (2014). Accountability, social responsibility and sustainability: Accounting for society and the environment. United Kingdom: Pearson Education Limited.

73. Halal, A., Gabasi, B., \& Firdause, N. (2014). An analysis of corporate governance and its impact on the firm's performance in Libya: (A Study in ENI oil and gas companies). Journal of Business and Management, 16(7), 6170. https://doi.org/10.9790/487X-16756170

74. Hamidi, D., \& Gabrielsson, J. (2014). Developments and trends in research on board leadership: A systematic literature review. International Journal of Business Governance and Ethics, 9(3), 243-268. https://doi.org/10.1504/IJBGE.2014.064739

75. Hamuda, K., \& Sawan, N. (2014). Perceptions of auditor independence in Libyan audit market. International Business Research, 7(2), 120-128. https://doi.org/10.5539/ibr.v7n2p120

76. Ho, P., Aripin, N., \& Tower, J. (2012). Corporate governance failure to influence the communication of key financial data over turbulent times. Journal of Applied Management Accounting Research, 10(10), 35-52.

77. Hoque, Z. (2006). Methodological issues in accounting research: Theories and methods. London: Spiramus Press Ltd.

78. Hussey, J., \& Hussey, R. (1997). Business research: A practical guide for undergraduate and postgraduate students. New York: Palgrave.

79. Hutchinson, M., \& Zain, M. (2009). Internal audit quality, audit committee independence, growth opportunities and firm performance. Corporate Ownership \& Control, 7(2), 50-65. http://doi.org/10.22495/cocv7i2p4

80. Iswaissi, H., \& Falahati, K. (2017). Challenges to corporate governance practices: Case study of Libyan commercial banks. Corporate Governance and Sustainability Review, 1(1), 33-41. http://doi.org/ $10.22495 /$ cgsrvli1p3

81. Jensen, M. C. (1993). The modern industrial revolution, exit, and the failure of internal control systems. The Journal of Finance, 48(3), 831-880. https://doi.org/10.1111/j.1540-6261.1993.tb04022.x

82. Judge, W., Douglas, T., \& Kutan, A. (2008). Institutional antecedents of corporate governance legitimacy. Journal of Management, 34(4), 765-785. https://doi.org/10.1177/0149206308318615

83. Jouha, F. (2015). Effect of corporate governance on corporate financial and market performance with sustainability reporting as intervening variable. South East Asia Journal of Contemporary Economics and Law, 6(1), 1-6. Retrieved from https://seajbel.com/wp-content/uploads/2015/05/Acc8_PAID_SEAJBEL_Ready-paperjournals-1.pdf

84. Jhunjhunwala, S., \& Sharvani, B. (2011). Corporate governance disclosure and transparency framework. Indian Journal of Corporate Governance, 4(1), 62-73. https://doi.org/10.1177/0974686220110105

85. Kang, H., Cheng, M., \& Gray, S. (2007). Corporate governance and board composition: Diversity and independence of Australian boards. Corporate Governance: A International Review, 15(2), $194-207$. https://doi.org/10.1111/j.1467-8683.2007.00554.x

86. Keasey, K., Thompsons, S., \& Wright, M. (1997). Corporate governance: responsibilities, risks \& remuneration. New York: John Wiley \& Sons.

87. Keay, A., \& Loughrey, J. (2015). The framework for board accountability in corporate governance. Legal Studies, 35(2), 252-279. https://doi.org/10.1111/lest.12058

88. Khalid, M., Alam, M., \& Said, J. (2016). Empirical assessment of good governance in the public sector of Malaysia. Economics \& Sociology, 9(4), 289-304. https://doi.org/10.14254/2071-789X.2016/9-4/18

89. Khiari, W., \& Karaa, A. (2013). Corporate governance and disclosure quality: Taxonomy of Tunisian listed firms using the decision tree method based approach. Journal of Applied Economics and Business Research, 3(2), 95-117.

90. Klapper, L., \& Love, I. (2004). Corporate governance, investor protection, and performance in emerging markets. Journal of Corporate Finance, 10(5), 703-728. https://doi.org/10.1016/S0929-1199(03)00046-4

91. Kribat, M., Burton, B., \& Crawford, L. (2013). Evidence on the nature, extent and determinants of disclosures in Libyan banks' annual reports. Journal of Accounting in Emerging Economies, 3(2), 88-114. https://doi.org/ $10.1108 / 20421161311288839$

92. La Porta, R., Lopez-de-Silanes, F., \& Shleifer, A. (1999). Corporate ownership around the world. The Journal of Finance, 54(2), 471-517. https://doi.org/10.1111/0022-1082.00115

93. Larbsh, M. (2010). An evaluation of corporate governance practice in Libya: Stakeholders' perspectives ( $\mathrm{PhD}$ thesis, University of Nottingham Trent). Retrieved from https://core.ac.uk/download/pdf/30624419.pdf

94. Law No. 11 (2010). Establishment of the Libyan Stock Market Authority (LSMA). Libyan Government, Tripoli, Libya.

95. Lemonakis, C., Malandrakis, I., Garefalakis, V., \& Balla, V. (2018). Corporate governance and internal audit: A review on performance indicators. Interdisciplinary Journal of Economics and Business Law, 7(1), 98-119. Retrieved from https://www.researchgate.net/profile/Alexandros_Garefalakis/publication/322746603_ Corporate_Governance_and_Internal_Audit_A_Review_on_Performance_Indicators/links/5a6ead39a6fdcc317b1 91d16/Corporate-Governance-and-Internal-Audit-A-Review-on-Performance-Indicators.pdf

96. Leuz, C., Nanda, D., \& Wysocki, D. (2003). Earnings management and investor protection: An international comparison. Journal of Financial Economics, 69(3), 505-527. https://doi.org/10.1016/S0304-405X(03)00121-1

97. Liao, L., Luo, L., \& Tang, Q. (2015). Gender diversity, board independence, environmental committee and greenhouse gas disclosure. The British Accounting Review, 47(4), 409-424. https://doi.org/ 10.1016/j.bar.2014.01.002

98. Low, D., Roberts, H., \& Whiting, R. (2015). Board gender diversity and firm performance: Empirical evidence from Hong Kong, South Korea, Malaysia and Singapore. Pacific-Basin Finance Journal, 35, 381-401. https://doi.org/10.1016/j.pacfin.2015.02.008

99. MacAvoy, P., \& Millstein, I. (2003). The recurrent crisis in corporate governance. Basingstoke: Palgrave

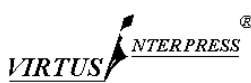


Macmillan. https://doi.org/10.1057/9781403946881

100. Mahadeo, J., \& Soobaroyen, T. (2016). A longitudinal study of the implementation of the corporate governance code in a developing country. Business \& Society, 55(5), 738-777. https://doi.org/10.1177/0007650313501838

101. Mallin, C. (2010). Corporate governance. Oxford: Oxford University Press.

102. Mallin, C. (2013). Corporate governance. Oxford: Oxford University Press.

103. Marciukaityte, D., Szewczyk, S., \& Varma, R. (2009). Voluntary vs forced financial restatements: The role of board independence. Financial Analysts Journal, 65(5), 51-65. https://doi.org/10.2469/faj.v65.n5.5

104. Masli, A. (2018). The role of audit committee as a corporate governance mechanism: The case of the banking sector in Libya ( $\mathrm{PhD}$ thesis, Nottingham Trent University). Retrieved from http://irep.ntu.ac.uk/id/eprint/ 35005/1/Thesis\%20of\%20Abdulhakim\%20Masli\%202018.pdf

105. Masoud, N. (2013). Libya's step towards change. Journal of World Economic Research, 2(4), 75-81. https://doi.org/10.11648/j.jwer.20130204.12

106. Melis, A., Gaia, S., \& Carta, S. (2015). Directors' remuneration: A comparison of Italian and UK non-financial listed firms' disclosure. The British Accounting Review, 47(1), 66-84. https://doi.org/10.1016/j.bar.2014.08.004

107. Meyer, J., \& Rowan, B. (1977). Institutionalized organizations: Formal structure as myth and ceremony. American Journal of Sociology, 83(2), 340-363. https://doi.org/10.1086/226550

108. Monks, R., \& Minow, N. (2004). Corporate governance (3rd ed.). Oxford: Blackwell Publishing.

109. Muniandy, B., \& Hillier, J. (2014). Board independence, investment opportunity set and performance of South African firms. Pacific-Basin Finance Journal, 35(A), 108-124. http://doi.org/10.1016/j.pacfin.2014.11.003

110. Murphy, A., \& Topyan, K. (2005). Corporate governance: A critical survey of key concepts, issues, and recent reforms in the US. Employee Responsibilities and Rights Journal, 17(2), 75-89. https://doi.org/10.1007/s10672005-3879-z

111. Nam, S., \& Lum, C. (2005). Survey of banks' corporate governance in Indonesia, Republic of Korea, Malasia and Thailand. Asian Development Bank Institute.

112. Nam, S., \& Nam, I. (2004). Corporate governance in Asia: Recent evidence from Indonesia, Republic of Korea, Malaysia, and Thailand. Asian Development Bank Institute. Retrieved from https://www.adb.org/sites/ default/files/publication/159384/adbi-corp-gov-asia.pdf

113. Ntim, C., \& Soobaroyen, T. (2013). Black economic empowerment disclosures by South African listed corporations: The influence of ownership and board characteristics. Journal of Business Ethics, 116(1), 121-138. https://doi.org/10.1007/s10551-012-1446-8

114. Ntim, C., Soobaroyen, T., \& Broad, M. (2017). Governance structures, voluntary disclosures and public accountability: The case of UK higher education institutions. Accounting, Auditing \& Accountability Journal, 30(1), 65-118. https://doi.org/10.1108/AAAJ-10-2014-1842

115. OECD. (2004). The OECD principles of corporate governance. Retrieved from https://www.oecd.org/daf/ca/ corporategovernanceprinciples/31557724.pdf

116. Okike, E. (2007). Corporate governance in Nigeria: The status quo. Corporate Governance, 15(2), 173-193. https://doi.org/10.1111/j.1467-8683.2007.00553.x

117. Okpara, J. (2011). Corporate governance in a developing economy: Barriers, issues, \& implications for firms. Corporate Governance: The International Journal of Business in Society, 11(2), 184-199. https://doi.org/ $10.1108 / 14720701111121056$

118. Oussii, A., \& Takatak, N. (2015). Internal audit function in Tunisian listed companies : An explanatory study. Research Journal of Finance and Accounting, 6(19), 92-103. Retrieved from https://www.researchgate.net/ publication/282945888

119. Parker, D. (2007). Financial and external reporting research: The broadening corporate governance challenge. Accounting and Business Research, 37(1), 39-54. https://doi.org/10.1080/00014788.2007.9730057

120. Patrick, E., Paulinus, E., \& Nympha, A. (2015). The influence of corporate governance on earnings management practices: A study of some selected quoted companies in Nigeria, American Journal of Economics, Finance and Management, 1(5), 482-493. Retrieved from https://www.researchgate.net/publication/324598815 The_Influence_of_Corporate_Governance_on_Earnings_Management_Practices_A_Study_of_Some_Selected_Quot ed_Companies_in_Nigeria

121.Pratten, J., \& Mashat, A. (2009). Corporate social disclosure in Libya. Social Responsibility Journal, 5(3), 311-327. https://doi.org/10.1108/17471110910977258

122. Prowse, S. (1998). Corporate governance: Emerging issues and lessons from East Asia. World Bank Group. Retrieved from The World Bank website: http://www.worlbank.org.

123. Rechner, P., \& Dalton, D. (1991). CEO duality and organizational performance: A longitudinal analysis. Strategic Management Journal, 12(2), 155-160. https://doi.org/10.1002/smj.4250120206

124. Reverte, C. (2009). Determinants of corporate social responsibility disclosure ratings by Spanish listed firms. Journal of Business Ethics, 88(2), 351-366. https://doi.org/10.1007/s10551-008-9968-9

125. Salterio, S., Conrod, J., \& Schmidt, R. (2013). Canadian evidence of adherence to "comply or explain" corporate governance codes: An international comparison. Accounting Perspectives, 12(1), 23-51. https://doi.org/ 10.1111/1911-3838.12006

126. Saunders, M., Lewis, P., \& Thornhill, A. (2009). Research methodology for business students (5 ${ }^{\text {th }}$ ed.). Harlow: Financial Times Prentice Hall. Retrieved from http://citeseerx.ist.psu.edu/viewdoc/download? doi=10.1.1.475.7307\&rep=rep1\&type=pdf

127. Shanikat, M., \& Abbadi, S. (2011). Assessment of corporate governance in Jordan: An empirical study. Australasian Accounting, Business and Finance Journal, 5(3), 93-106. Retrieved from https://ro.uow.edu.au/cgi/viewcontent.cgi?referer=https://www.google.com/\&httpsredir=1\&article=1209\&cont ext=aabfj

128. Shiri, M., Salehi, M., \& Radbon, A. (2016). A study of impact of ownership structure and disclosure quality on information asymmetry in Iran. The Journal for Decision Makers, 41(1), 51-60. https://doi.org/ $10.1177 / 0256090915620876$

129. Sinclair, A. (1995). The chameleon of accountability: forms and discourses. Accounting, Organizations and Society, 20(2-3), 219-237. https://doi.org/10.1016/0361-3682(93)E0003-Y

130. Solomon, J. (2010). Corporate governance and accountability. London: John Wiley \& Sons Ltd.

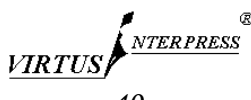


131. Solomon, J. (2013). Corporate governance and accountability. London: John Wiley \& Sons Ltd.

132. Solomon, J., \& Solomon, A. (2004). Corporate governance and accountability. England: Chichester: John Wiley.

133. Steger, T. (2014). What have we not researched? And why not? - Some reflections on the "blind spots" of corporate governance and board research. International Journal of Business Governance and Ethics, 9(2), 121135. https://doi.org/10.1504/IJBGE.2014.063276

134. Sternberg, E. (2004). Corporate governance: Accountability in the market place (2nd ed.). London, England: Institute of Economic Affairs.

135. Suchman, M. (1995). Managing legitimacy: Strategic and institutional approaches. Academy of Management Review, 20(3), 571-610. http://doi.org/10.2307/258788

136. Summers, J., \& Nowicki, M. (2006). Pricing transparency or smoke screen? Journal of the Healthcare Financial Management Association, 60(12), 134-136.

137. Suwaidan, M., \& Qasim, A. (2010). External auditors' reliance on internal auditors and its impact on audit fees. Managerial Auditing Journal, 25(6), 509-525. https://doi.org/10.1108/02686901011054845

138. The Combined Code (2006). Combined Code, Principles of Corporate Governance. London: The London Stock Exchange Limited.

139. The LCGC (2005). Issuing the Libyan Corporate Governance Code (LCGC) for the banking sector. The Central Bank of Libya.

140. The LCGC (2007). Issuing the Libyan Corporate Governance Code (LCGC) for Libyan listed companies. The Libyan Stock Market.

141. The LCGC (2010). Issuing the Libyan Corporate Governance Code (LCGC) for the banking sector. The Central Bank of Libya.

142. The Libyan Commercial Law (1972). Amending version of LCL of 1953. Libyan Encyclopaedias of Financial Legislation.

143.Tulung, J., \& Ramdani, D. (2018). Independence, size and performance of the board: An emerging market research. Corporate Ownership \& Control, 15(2), 201-208. http://doi.org/10.22495/cocv15i2c1p6

144. Union of Arab Banks (UAB). (2007). Survey results: Corporate governance survey of the Arab banking sector. Retrieved from http://docplayer.net/28805940-Corporate-governance-survey-of-the-arab-banking-sector.html

145. Vaismoradi, M., Turunen, H., \& Bondas, T. (2013). Content analysis and thematic analysis: Implications for conducting a qualitative descriptive study. Nursing and Health Sciences, 15(3), 398-405. https://doi.org/ $10.1111 /$ nhs. 12048

146. Volonté, C. (2015). Boards: independent and committed directors? International Review of Law and Economics, 41, 25-37. https://doi.org/10.1016/j.irle.2014.10.002

147. Wahba, H. (2015). The joint effect of board characteristics on financial performance: Empirical evidence from Egypt. Review of Accounting and Finance, 14(1), 20-40. https://doi.org/10.1108/RAF-03-2013-0029

148. Weir, C., Laing, D., \& Mcknight, P. (2002). Internal and external governance mechanisms: Their impact on the performance of large UK public companies. Journal of Business Finance \& Accounting, 29(5-6), 579-611. https://doi.org/10.1111/1468-5957.00444

149. Wong, D. (2009). An assessment of corporate governance reforms in the Philippines: 2002-2009. Philippine Management Review, 16, 24-57. Retrieved from https://www.academia.edu/9732071/ AN_ASSESSMENT_OF_CORPORATE_GOVERNANCE_REFORMS_IN_THE_PHILIPPINES_2002_2009

150. Yoo, J., \& Reed, R. (2015). The effects of top management team external ties and board composition on the strategic choice of late movers. Long Range Planning, 48(1), 23-34. https://doi.org/10.1016/j.lrp.2013.08.002

151.Zakari, M., \& Elshahoubi, I. (2018). Corporate governance practices in the Libyan environment. In D. Jamali, V. Bodolica, \& Y. Lapina (Eds.), Corporate governance in Arab countries: Specifics and outlooks (pp. 44-69). Ukraine: Virtus Interpress.

152.Zattoni, A., \& Judge, W. (2012). Corporate governance and initial public offerings: An international perspective. UK: Cambridge University Press. https://doi.org/10.1017/СBO9781139061513 